\title{
Identidade e alteridade: o jogo do amor e da poesia em Vinicius de Moraes
}

Márcia Helena S. Barbosa"

\section{Resumo}

Este artigo procede à análise da obra poética de Vinicius de Moraes, a fim de mostrar que, na obra desse autor, a questão da identidade e da alteridade está imbricada com a temática do amor. A perda de si, desencadeada no sujeito pelo amor, é que dá acesso a uma experiência ainda mais radical de alteridade: a despersonalização do eu na linguagem, na poesia. $O$ fato de que o amor, em sua presença ou ausência, é a via encontrada pelo eu lírico para constituir-se como poeta fica evidenciado pelo modo como os poemas examinados encenam a relação que o sujeito estabelece não apenas com a amada, mas também com a paisagem. Para a análise da poesia de Vinicius de Moraes sob a ótica da identidade e da alteridade, adota-se a perspectiva da crítica temática de base francesa, tomando como suporte as teses enunciadas por Michel Collot sobre a constituição da subjetividade e sobre as relações do sujeito com o espaço, bem como acerca dos aspectos que a experiência poética e a experiência amorosa têm em comum.

Palavras-chave: Identidade. Alteridade. Paisagem. Experiência poética. Experiência amorosa.

\section{Introdução}

A abordagem da questão da identidade e da alteridade pode conduzir ao redimensionamento do tema do amor na poesia de Vinicius de Moraes. A análise de poemas incluídos em livros escritos e publicados pelo autor em diferentes momentos, entre os anos 30 e a década de 60, será desenvolvida neste trabalho com o objetivo de demonstrar que, em sua obra, as duas temáticas aqui destacadas imbricam-se, na medida em que o sujeito constrói sua identidade como poeta e vê-se alçado a essa condição por meio do descentramento que nele o amor provoca. A perda de si desencadeada

\footnotetext{
Professora de Literaturas de Língua Portuguesa do Programa de Pós-Graduação e do Curso de Letras da Universidade de Passo Fundo. Doutora em Teoria da Literatura pela Pontifícia Universidade Católica do Rio Grande do Sul. Vinculada ao Grupo de Pesquisa Estudos de Paisagem nas Literaturas de Língua Portuguesa da Universidade Federal Fluminense e ao Grupo de Ensino de Literatura da Universidade de Passo Fundo. E-mail: mhsbarbosa@gmail.com
}

Data de submissão: mar. 2016 - Data de aceite: maio 2016 http://dx.doi.org/10.5335/rdes.v12i1.5884 
por esse sentimento é que dá acesso a uma experiência ainda mais radical de alteridade: a despersonalização do eu na linguagem, a sua perda substancial na poesia. $\mathrm{O}$ fato de que o amor, em sua presença ou ausência, é a via encontrada pelo eu lírico para constituir-se como poeta fica evidenciado pelo modo como os versos examinados encenam a relação que o sujeito estabelece não apenas com a amada, mas também com a paisagem. A reação desse sujeito masculino diante das mulheres e das paisagens - que se situam perto ou longe de si - desvela a dialética do próximo e do distante como o elemento que rege a própria existência do eu.

\section{Paisagem, estrutura de horizonte e alteridade}

Para a análise da poesia de Vinicius de Moraes sob a ótica da identidade e da alteridade, adota-se a perspectiva da crítica temática de base francesa, tomando como suporte as teses enunciadas por Michel Collot. Os estudos teórico-críticos desse pesquisador, que é também poeta, fundamentam a discussão da temática proposta e permitem um aprofundamento da reflexão sobre a constituição da subjetividade e sobre as relações do sujeito com o espaço, bem como acerca dos aspectos que a experiência poética $\mathrm{e}$ a experiência amorosa têm em comum.

No que se refere ao primeiro tópico, é importante retomar algumas ideias relativas à noção de paisagem que o teórico formula recorrendo, sobretudo, à fenomenologia, em especial às teses de Merleau-Ponty sobre experiência de mundo e percepção. A paisagem é concebida por Collot (2010) como um dado construído e simbólico, como uma construção da subjetividade, pois a percepção do espaço não se limita à recepção passiva de dados sensoriais, mas pressupõe a organização capaz de lhes dar um sentido. Desse modo, "pode-se dizer [...] que a paisagem, segundo a crítica temática, une estreitamente uma imagem de mundo, uma imagem do eu, e uma construção de palavras" (COLLOT, 1997, p. 192). Além disso, Collot (2010; 2012) esclarece que a estrutura de horizonte é um conceito-chave para a teorização da paisagem e da relação que o sujeito estabelece com o espaço, o outro e a linguagem. O teórico apresenta as características dessa organização perceptiva, as quais indicam que não há paisagem sem horizonte, tal o elo existente entre ambos. Essas características estão relacionadas às ideias de ponto de vista, de extensão, de parte e de unidade ou conjunto.

A primeira noção é a de que a paisagem é definida do ponto de vista a partir do qual é examinada, ou seja, é sempre vista por alguém de algum lugar e, por essa razão, é que possui um horizonte. A atividade constituinte de um sujeito é condição da existência da paisagem. Collot (2012, p. 13) afirma que aquele que vê não se situa diante da paisagem numa relação de exterioridade: ela é apenas uma perspectiva cujos contornos 
se confundem com os do campo visual do sujeito. O estudioso acrescenta, ainda, que a paisagem não é somente vista, mas também habitada e vivida, e que o horizonte é que permite ao sujeito transformá-la em seu território, como espaço ao alcance do olhar e à disposição do corpo. A possibilidade de se investir na paisagem qualquer tipo de conteúdo psicológico é explicado por essa conivência que o olhar e o corpo inteiro mantêm com ela. $O$ fato de a paisagem refletir os estados de alma é o que leva Collot a pensar na busca ou eleição de um horizonte privilegiado como uma forma de busca de si mesmo: "Por que preciso de uma paisagem quando procuro reapoderar-me de minha própria identidade? Se não é porque, toda consciência sendo consciência de..., ela pode definir-se apenas por seu horizonte" (2010, p. 207).

A segunda ideia é a de que o sujeito possui existência somente através de um espaço oferecido ao desdobramento de seus poderes, o que lhe é garantido pela extensão da paisagem, "que o define como ek-sistente sempre à distância de si". Essa extensão favorece uma presença de si que deve ser entendida "como uma maneira de ser "perto de si do outro lado de si, em uma proximidade inaproximável", e não como uma identidade já definida e fechada sobre si mesma (COLLOT, 2010, p. 207). O horizonte é, assim, a imagem do futuro. Collot resume a correspondência entre horizonte $\mathrm{e}$ subjetividade, paisagem e existência, na passagem a seguir:
A distância que me une ao horizonte ao mesmo tempo em que ela dele me separa corresponde à própria estrutura da subjetividade, cujo destino é ter que encontrar-se para além de uma distância sempre mantida de si para si. A dialética do próximo e do longínquo rege tanto a paisagem como a existência; ela possui um significado indissociavelmente espacial ou temporal (2010, p. 208).

A profundeza do espaço, que corresponde alegoricamente à profundeza do tempo, é a imagem da "amplidão da vida" - "lá, é daqui a pouco ou amanhã" -, fundamental para que a existência possa desabrochar ou arrebatar-se em direção ao futuro (COLLOT, 2010, p. 208).

A terceira noção diz respeito ao aspecto parcial da paisagem. A parte da região que ela oferece ao olhar é determinada pela extensão do campo visual do espectador e pelo relevo do espaço observado. Assim, o ponto de vista adotado exclui as demais perspectivas. Collot (2010; 2012) distingue o horizonte externo do horizonte interno: o primeiro é uma linha que circunscreve a paisagem e além da qual mais nada é visível; o segundo é constituído pela existência de partes não visíveis no interior do campo delimitado. Essa limitação da visibilidade faz surgirem lacunas que convertem a paisagem numa estrutura de apelo, isto é, sendo incompleta, a paisagem pede para ser completada pela percepção, e o sujeito, por meio de uma intervenção ativa, pode preencher tais lacunas graças à imaginação, à palavra ou ao movimento. Desse modo, "o horizonte é poético porque é um convite perpétuo para recriar a paisa- 
gem", "porque abre nesta uma dimensão de alteridade" (COLLOT, 2010, p. 211). Essa alteridade possui um significado intrassubjetivo, pois mobiliza no sujeito as potências da lembrança e da imaginação, e uma dimensão intersubjetiva, porque as falhas no visível são também aquilo que relaciona o campo visual do sujeito com os de outros sujeitos: aquilo que ele não vê é o que pode ser visto pelo Outro. O horizonte torna-se objeto de desejo na medida em que é o lugar do Outro e convida, assim, a explorar outros mundos. Collot (2010, p. 212) conclui afirmando que o horizonte é um não lugar, "utopia do desejo", e supõe que é talvez pelo fato de ele ser "um objetivo inacessível" para o movimento que se torna para a fala "um objeto privilegiado: na falta de poder transportar-se até ele, o poeta tentará aproximá-lo por metáforas".

A quarta ideia é a de que a limitação do espaço visível assegura a unidade da paisagem, constituindo-a como uma totalidade coerente, um todo homogêneo. $\mathrm{O}$ horizonte funda a coesão da paisagem ao excluir os elementos heterogêneos. Esse enquadramento perceptivo é que faz a paisagem ser percebida como um objeto estético, isto é, ser apreciada em termos de belo ou feio. É também em virtude desse enquadramento que a paisagem apresenta a tensão essencial a qualquer obra de arte, entre o advento de uma forma ou a constituição de uma estrutura e sua abertura a um fundo abissal, ao invisível, tornando-se uma unidade perceptiva e estética, e, ao mesmo tem- po, uma unidade de sentido. Portanto, o horizonte, ao opor-se à paisagem, é "o negativo necessário à emergência do positivo". Trata-se de "uma verdadeira estrutura" - e não de um mero componente, entre outros, da paisagem -, "que condiciona a emergência de um 'sentido dos sentidos"' (COLLOT, 2010, p. 215). Essa estrutura de horizonte, fazendo da paisagem um conjunto pré-simbólico, permite que nela se esboce um sentido, mas a impede de petrificar-se em um sistema fechado de significados.

\section{A experiência poética e a experiência amorosa como saída de si}

As teses formuladas por Collot (1989) acerca das convergências existentes entre a experiência poética e a experiência amorosa, como se verá a seguir, relacionam-se intimamente à noção de paisagem e, de modo especial, ao conceito de estrutura de horizonte. Segundo o teórico, a experiência poética é, fundamentalmente, saída de si. Na experiência e na escrita poéticas, o sujeito engajado na travessia do mundo e da linguagem, que é sempre mais ou menos um moiuma personalidade com características individuais e uma história singular -, tende a tornar-se um je, isto é, um ser definido pela fala que profere e que é levado ao encontro dos outros, das coisas e de sua própria alteridade, de seu inconsciente. O eu que aí se exprime é um Outro, estabelecendo-se, assim, um 
espaço aberto que pode ser ocupado por qualquer um, para vivenciar a experiência poética. E a existência de pontos em comum entre 0 amor e a poesia reside no fato de que ambos abrem à humanidade uma "margem" de jogo e de liberdade. "No jogo sério do amor e da poesia", explica o teórico, "tudo se acha convertido em jogo: o eu, o mundo e as palavras aí perdem seus contornos e sua identidade, para 'tomar corpo de horizonte', quer dizer, abrir-se a uma dimensão de alteridade que os transfigura e os ilimita" ${ }^{2}$ (COLLOT, 1989, p. 93).

O poeta é aquele que adota sistematicamente o ponto de vista do Outro, pois vê o mundo e as palavras com os olhos de seu leitor. É "para ver de outro modo as coisas que 'a imaginação poética... renuncia à sua soberania, à autoridade de seu ponto de vista", assumindo o do outro ${ }^{3}$ (COLLOT, 1989, p. 90). A "passagem ao horizonte" - que é o lugar do Outro, e que se caracteriza como abertura do espaço ao ilimitado - metaforiza essa passagem ao "outro campo". Tal referência a outrem pode revelar perspectivas originais e novas no interior mesmo do mundo comum, inaugurando, então, "um horizonte, que não é mais o Desconhecido radical, mas uma reserva inesgotável aberta ao conhecimento"4 (COLLOT, 1989, p. 89). Portanto, essa conversão de ponto de vista confere ao mundo conhecido uma profundidade insuspeitável, de modo que a transcendência se inscreve no coração da imanência. Isso permite ao olhar surpreender o estranho no cerne do familiar, e possibilita à escrita restituir às palavras mais usadas um horizonte de sentido.

O encontro do Outro, segundo Collot (1989), promove a abertura do corpo, do mundo e da linguagem ao infinito do desejo, na medida em que desfaz o "nó" das representações e das locuções cristalizadas, da visão de mundo estereotipada. É por essa mesma razão que o amor, a exemplo do que ocorre com a experiência poética, faz as divisões e os limites se dissiparem. Tal abertura, de que o encontro do Outro mostra-se inseparável, é abissal, pois se efetua na direção do horizonte das coisas, isto é do invisível e do infinito. Assim, o encontro do Outro "revela, para além do cosmos ordenado e acabado, um mundo inteiro em estado nascente" ${ }^{\text {. Trata-se de um }}$ caos rico de possibilidades e é por esse motivo que, "na relação amorosa, a 'terra' 'se perde' antes de se descobrir 'nova"'6 (COLLOT, 1989, p. 94, grifo do autor).

Segundo o teórico (1989), é porque a invisibilidade do Outro faz dele um horizonte indevassável, e porque nele o sujeito perde toda faculdade de ver, que esse Outro pode abrir-lhe o mundo a perder de vista. É devido a sua intervenção que os objetos se acrescentam de uma face escondida e parecem se ausentar, pois o centro da perspectiva que, além, os reúne se subtrai à visão do sujeito. Embora o eu e o Outro tenham em comum um mesmo mundo, seus pontos de vista não são intercambiáveis. O próprio Outro, por mais próximo e íntimo que 
seja do eu, jamais está presente senão através de certa ausência. A sua consciência, a sua interioridade - em torno da qual se reorganiza um mundo que escapa ao sujeito - é o lugar de uma espécie de vazio, de lacuna que o corpo do Outro desenha no espaço. É como se o olhar do Outro opusesse à curiosidade do sujeito uma espécie de véu transparente, teia essa que o desejo ciumento desejaria levantar, porém a interioridade do ser amado parece daí se retirar num abismo tão insondável quando o do horizonte. Por isso, o ato de metaforizar o Outro como horizonte corresponde, frequentemente, a uma valorização do mistério e da estrangeiridade por parte do sujeito.

Essa relação com o Outro leva o teórico a concluir que, na experiência amorosa, a inserção de uma infinidade de pontos de vista no campo perceptivo do sujeito depende de um ser cuja percepção completa é impossível. Assim, o visível se funda sobre a invisibilidade, e nisso reside o paradoxo da alteridade. $\mathrm{O}$ "olhar do Outro" é "o centro visível desse ponto de vista sobre o mundo que me restará sempre invisível", de forma que nele se reúnem exemplarmente a evidência e o enigma (COLLOT, 1989, p. 97, grifo do autor). A vida interior aflora e se oculta, inclusive ao mesmo tempo, nos olhos do ser amado, razão pela qual, para alguns, o amor implica a distância - não a fusão - que faz do Outro um horizonte inesgotável e insondável. Se o ser amado fosse dado ao sujeito de maneira plena e inteira, deixaria de ser um objeto de desejo. Além disso, como afirma Collot, "se o amor conduzisse a uma total fusão das consciências, não daria mais lugar à fala nem à poesia", pois é "justamente na medida em que outrem me é invisível que ele me fala, e que sinto a necessidade de falar-lhe e de falar dele" ${ }^{\text {. A presença }}$ do outro, que não é dada a ver, é dada a perceber através da expressividade de um corpo e de uma linguagem, signos que instauram entre os amantes uma comunicação a distância, comparável àquela que se estabelece entre o sujeito $\mathrm{e}$ o horizonte. Esse fato sugere que o amor e a poesia são "o deciframento sempre recomeçado desses signos enigmáticos vindos do Outro ou do horizonte" (COLLOT, 1989, p. 99).

\section{O amor a todas as mulheres e o "Supremo Impossível"}

Pode-se verificar como o amor dá lugar à poesia na obra de Vinicius de Moraes com base nas ideias e conceitos de Michel Collot retomados nas seções anteriores. No poema intitulado "Minha mãe" (MORAES, 1974, p. 84) e incluído em $O$ caminho para a distância, o poeta canta o "medo da vida". A inquietude do eu lírico, que rouba de seus olhos a luz e o repouso, é uma "angústia imensa" advinda da consciência de que toda escolha pressupõe uma renúncia. Não há como fugir da necessidade de optar. Por isso, o sujeito poético deseja aninhar-se no colo da mãe "como outrora", para que ela se 
encarregue de afugentar tanto o espaço que o prende como o infinito que o chama e, assim, ele não precise escolher entre um e outro. Não se trata, entretanto, de uma dupla renúncia: não ficar, nem partir. Na imaginação do eu lírico, a solução mágica oferecida pela figura materna àquele que volta a ser criança reside na possibilidade de uma dupla escolha, isto é, ficar e partir: "Minha mãe, minha mãe, eu tenho medo/ Me apavora a renúncia. Dize que eu fique/ Dize que eu parta, ó mãe, para a saudade./ Afugenta este espaço que me prende/ Afugenta o infinito que me chama [...]".

Esses verbos - ficar e partir, escolher e renunciar - e também os substantivos aos quais estão relacionados - prisão e infinito - dizem muito não apenas sobre o amor nos versos de Vinicius de Moraes, mas também sobre o modo como o escritor vê a própria poesia e, acima de tudo, acerca dos elos que ligam essas duas temáticas na obra do autor. Por sua vez, o poema denominado "O poeta na madrugada” (MORAES, 1974, p. 88), que faz parte do mesmo livro, não fala do sonho de retorno à infância, mas da maneira pela qual o eu lírico pensa garantir para si a eterna juventude e, consequentemente, a condição de poeta. Diz o texto que, quando "chegou à cidade", o poeta foi amado pelas mulheres - que beijaram a sua fronte, além de rogarem o seu amor - e, logo depois, seguido por elas. Entretanto, esse sentimento que o une às mulheres é justamente o que $o$ estimula a deixá-las:

O poeta tem a alegria que vive na luz

E tem a mocidade que nasce da luz.

As mulheres seguiram o poeta

Oferecendo a tristeza do seu amor e a alegria da sua carne

$\mathrm{O}$ poeta amou a carne das mulheres

Mas não envelheceu no amor que elas lhe davam.

O poeta quando ama

É como a flor que murcha sem seiva

Porque o amor do poeta

É a seiva do mundo

E se o poeta amasse

Ele não viveria eternamente jovem, brilhando na luz.

Quando a nova madrugada raiou no céu distante

O poeta já tinha partido

E seguindo o poeta as mulheres de peitos fartos e de cântaros cheios

Falavam de ardentes promessas de amor. 
De acordo com o sujeito poético, para manter "a mocidade que nasce da luz", o poeta deve apenas amar "a carne das mulheres", evitando a permanência do/ no amor. Quando o poeta experimenta a constância desse sentimento, ou seja, quando envelhece no afeto que lhe é dado, o seu amor deixa de alimentar-se da "seiva do mundo". Desse modo, ele precisa partir antes do raiar da "nova madrugada", pois, caso aceitasse ser alimentado pelos "peitos fartos" e os "cântaros cheios" que as mulheres possuem, viria a tornar-se uma flor murcha. Nos primeiros versos de "Cântico" (MORAES, 1974, p. 200-201) - que integra o livro Poemas, sonetos e baladas -, percebe-se que o eu lírico adota uma atitude mais extremada do que essa, manifestando a vontade de nunca ter a amiga. A posse, a concretização do amor, pode levar ao esgotamento do desejo, então, ele quer a amada ausente, para jamais perdê-la. Se ela permanecer em seu pensamento como ideia, o desejo, porque não saciado, será mantido: “[...] Ah, fosses nunca/ Minha, fosses a ideia, o sentimento/ Em mim, fosses a aurora, o céu da aurora/ Ausente, amiga, eu não te perderia!".

Em "Ausência" (MORAES, 1974, p. 99), poema de Forma e exegese, reitera-se a ideia exposta em "O poeta na madrugada”, a de que impedir a exaustão do desejo é deixar que ele morra, é não persistir nele. Para isso, é necessário ir embora: "Eu deixarei que morra em mim o desejo de amar os teus olhos que são doces/ Porque nada te poderei dar senão a mágoa de me veres eternamente exausto./ [...] Não te quero ter porque em meu ser tudo estaria terminado [...]". A seguir, o eu lírico acrescenta que, depois de sua partida, possuirá a amada "mais que ninguém", porque os sons emitidos pelos elementos da natureza, interpretados por ele como "lamentações", serão a presença da voz ausente da mulher. Essa voz, ao expressar o sofrimento da perda e a saudade - e não mais a fúria do desejo -, já terá se transformado, então, em "voz serenizada".

Ainda segundo as afirmações feitas nesse poema, a presença da amada é "qualquer coisa como a luz e a vida", mas tê-la, como se viu antes, significa apagar o desejo que mantém acesa a alegria e a mocidade do poeta. Assim, o homem que, para preservar a sua condição de poeta, tem de viver "eternamente jovem" identifica-se com "O poeta aprendiz" (MORAES, 1974, p. 307-309), que dá título a um texto de Para viver um grande amor e que é definido deste modo: "Amava era amar". Esse, que faz do próprio ato de amar o seu objeto de desejo e que, muitas vezes, não se conforma em ter a amada somente como ideia por meio da união espiritual com ela, quer tomar como par "A mulher que passa" (MORAES, 1974, p. 143-144), num poema assim intitulado e incluído em Novos poemas: 
Meu Deus, eu quero a mulher que passa!

[...]

Que vens e passas, que me sacias

Dentro das noites, dentro dos dias!

Por que me faltas, se te procuro?

Por que me odeias quando te juro

Que te perdia se me encontravas

E me encontrava se te perdias?

[...]

Que fica e passa, que pacifica

Que é tanto pura como devassa

Que boia leve como a cortiça

$\mathrm{E}$ tem raízes como a fumaça.

A "mulher que passa" sacia e pacifica momentaneamente o desejo do eu lírico, mas esse não é um amor no qual se possa envelhecer, uma vez que ele não dispõe de tempo para se aprofundar, ou ultrapassar a superfície, de forma que suas raízes se dissipam no ar. Passar e ver passar é o que faz durar o desejo. Portanto, o sujeito poético de Vinicius de Moraes, não querendo - ou não suportando - "estar preso por vontade", como o eu lírico de Camões (1992, p. 16), a um único espaço, a um mesmo corpo, a um amor incapaz de manter-se sempre jovem, torna-se prisioneiro do constante anseio de partir. É por isso que, em "A queda” (MORAES, 1974, p. 103- 104), poema de Forma e exegese, ele exibe com orgulho sua "natureza" indomável, que lhe permite resistir a qualquer tentativa feita pela amada de dominá-lo ou domesticá-lo: "Tu te abaterás sobre mim querendo domar-me mas eu te resistirei/ Porque a minha natureza é mais poderosa que a tua”. É também por esse motivo que ele anuncia sua decisão de abandonar a mulher logo após a consumação do amor que os unira: “[...] $\mathrm{E}$ ao sol te abrirás toda para as núpcias sagradas./ [...] Depois eu partirei como um animal de beleza, pelas montanhas/E teu pranto de saudade estará nos meus ouvidos em todas as caminhadas". Mais uma vez, o sujeito poético indica que não deve ser seguido pelas mulheres que 0 amarem. A única acompanhante aceita e desejada por aquele que, dessa maneira, acredita preservar sua condição de poeta é a lembrança - que guardará em sua memória auditiva - do sofrimento feminino, dor, aliás, provocada pela saudade que ele próprio deixou ao afastar-se. Portanto, somente os rastros de sua suposta superioridade é que ele poderá tolerar.

Mesmo desejada, entretanto, a partida parece impossível em algumas ocasiões, como se constata em outro poema de Forma e exegese intitulado "A impossível partida” (MORAES, 1974, p. 117). Para poder penetrar a "noite erma" e deixar-se arrebatar por "mãos desconhecidas", o eu lírico tem de abandonar o passado ao qual está aprisionado "como uma criança ao colo materno”; antes, porém, precisa "adormecer" nessa "lembrança boa". E assim, adormecido, ele vê os seus sentidos entorpecerem ou murcharem "como vão murchando as rosas colhidas" - comparação que remete à imagem antes comentada do poeta que é "como a flor murcha" quando ama -, o que o torna incapaz de "viver misteriosamente" os segredos da noite, conforme se lê no seguinte fragmento: 
Como poder-te penetrar, ó noite erma, se os meus olhos cegaram nas luzes da cidade

E se o sangue que corre no meu corpo ficou branco ao contato da carne indesejada?...

Como poder viver misteriosamente os teus recônditos sentidos

Se os meus sentidos foram murchando como vão murchando as rosas colhidas [...]?

Se estou preso ao passado como a criança ao colo materno

E se é preciso adormecer na lembrança boa antes que as mãos desconhecidas me arrebatem?...

Embora difícil, a partida revela-se, na poesia do escritor, uma impossibilidade apenas momentânea, porque, para o eu lírico, o coração não é maior que a alma, nem a presença é melhor que a saudade, como se lê em "Soneto de contrição" (MORAES, 1974, p. 150-151), que integra Novos poemas. Se o apelo do infinito é mais intenso do que o amor permanecido, o sujeito poético prefere a ausência e a saudade à presença física da amada. Amar é "sentir calma", mas essa calma se confunde com a humildade, com o desapego, de modo que, na equação formulada pelo sujeito poético, quanto mais forte for a sensação de que a conquista está consumada menor será a sua permanência ao lado da amada. Por isso, após confessar seu amor por Maria, ele declara: "Só te amar é divino, e sentir calma...// E é uma calma tão feita de humildade/ Que tão mais te soubesse pertencida/ Menos seria eterno em tua vida".

A eternidade, como se observa nesse poema, não é uma categoria absoluta: o amor pode ser mais ou menos eterno dependendo de sua capacidade de propiciar ao eu lírico a calma ou o mistério. No poema intitulado "Princípio" (MORAES, 1974 , p. 149-150), que faz parte desse mesmo livro, ele define de maneira pre- cisa o sentido da sua busca, ao rejeitar "a superfície calma" das águas e ao optar por aquilo que, no mar, é "abismo", desconhecido e mistério: "[...] O mar! (Não a superfície calma, mas o abismo povoado de peixes fantásticos e sábios...)". Se o poeta deseja as profundezas desse abismo, é porque nele a sua alma se reconhece; ela, que "é uma parcela do infinito distante", assemelha-se a esse mar sem fim, como se verifica no poema de $O$ caminho para a distância intitulado "O poeta" (MORAES, 1974, p. 73): "O poeta é o destinado do sofrimento/ Do sofrimento que lhe clareia a visão de beleza/ $\mathrm{E}$ a sua alma é uma parcela do infinito distante/ O infinito que ninguém sonda e ninguém compreende". A "vida do poeta" tem, portanto, "um ritmo diferente/ Ela o conduz errante pelos caminhos, pisando a terra e olhando o céu [...]".

A errância caracteriza os movimentos do poeta e o leva a manter o olhar voltado para o infinito - o céu ou o mar -, enquanto seus pés pisam a terra. Dessa forma, sua vida, que é "um contínuo de dor angustiante", tem um ritmo distinto daquele que marca a existência dos demais, como o eu lírico mostra no poema acima comentado e como reafirma nos versos de "Solilóquio" (MORAES, 1974, p. 151-153), em Novos poemas. Neste 
último texto, o sujeito poético, ainda que se declare "cansado de sofrer", situa num tempo indefinido e num lugar também indefinido a possibilidade de "lançar [...] as âncoras ardentes das promessas". Além disso, contrapõe a essa possibilidade de ser como os outros a intranquilidade de seu coração, que deseja tudo aquilo que não é passado, tudo aquilo que não viveu. Ele revela sentir "fome e sede" apenas de "lembranças inexistentes", como se alertasse "o que em mim lembra está imaginando", para recorrer a uma paráfrase do conhecido verso de Fernando Pessoa que diz: "o que em mim sente está pensando" (PESSOA, 1995, p. 144). Assim, incapaz de deter-se nos "limites da pátria" devido a uma ânsia de viajar rumo ao desconhecido, o eu lírico aparta-se dos "puros", apresentando-se como aquele que traz em seu coração a descrença, e não a pureza: "Talvez os imensos limites da pátria me lembrem os puros/ E amargue em meu coração a descrença."

Perdido no mar é como os outros o veem: "Bem viram os que temeram a minha angústia e as que disseram:/ Ele perdeu-se no mar!”. O sujeito poético concorda com a opinião alheia, todavia complementa esse pensamento, afirmando: "No mar estou perdido, sem céu e sem terra e sem sede de água". Ele sabe que não se distingue dos demais somente por estar perdido no mar, mas também porque não deseja o mesmo que eles, ou porque não deseja aquilo pelo qual anseiam todos os que se encontram à deriva. São os apelos vindos do silêncio que o atraem, e ele nada pode "senão ir e vir como a sombra do condenado/ Pelo silêncio em escuta...”. A seguir, o sujeito poético mostra que, por não conseguir ser como os demais, sente-se covarde no olhar dos que o amam, embora não se reconheça como tal, pelo fato de experimentar um sofrimento constante. Sendo diferente, vê-se, simultaneamente, "tão grande, tão pequeno...”. Essa condição paradoxal gera uma dúvida que dá origem a duas hipóteses em forma de pergunta, a primeira das quais parece reproduzir uma acusação feita pelos outros, enquanto a segunda soa como uma resposta do eu lírico a essa recriminação: "Serei vazio de amor como os ciprestes/ No seio da ventania?/ Serei vazio de serenidade como as águas no seio do abismo/ Ou como as parasitas no seio da mata serei vazio de humildade?/ Ou serei o amor eu mesmo e a calma e a humildade eu mesmo/ No seio do infinito vazio?" O eu lírico sugere nesses versos que ele próprio é a encarnação de tudo o que em si parece faltar.

Diferentemente de todos - os puros, os crentes -, que deixam a casa onde moram apenas por algumas horas, a fim de participarem de celebrações e ritos, cerimônias feitas de ações que se repetem e, portanto, de uma sequência previsível, o eu lírico ficará em casa, porém sem lar, sem guarida, absolutamente solitário. Ele sabe que há "amantes que não se entediam" e amigos que permanecem juntos a despeito da paixão já exauri- 
da, mas se mantém distante de todos eles e afastado de ambas as situações. Assim, enquanto os demais se atêm aos "limites da pátria", o sujeito poético é o único que traz dentro de si o ilimitado e, por isso, até mesmo quando permanece, fica "sem perseverança": "Ficarei em casa, sem lar [...].// Mas oh, cerrar os olhos, dormir, dormir longe de tudo/ Longe mesmo do amor longe de mim!/ E enquanto se vão todos, heroicos, santos, sem mentira ou sem verdade/ Ficar, sem perseverança...". Nesse poema de Vinicius de Moraes parecem ressoar alguns versos de Fernando Pessoa, que dizem: "Outros terão/ Um lar, quem saiba, amor, paz, um amigo./ A inteira, negra e fria solidão está comigo.// A outros talvez/ Há alguma coisa quente, igual, afim./ No mundo real. Não chega nunca a vez/Para mim". (PESSOA, 1995, p. 494)

O texto intitulado "A vida vivida" (MORAES, 1974, p. 154-155), que também integra Novos poemas, dá continuidade a essa ideia, pois aí o eu lírico se apresenta como o eterno peregrino - aquele que, em vez de participar de celebrações e ritos, escolhe a aventura -, definindo o seu Amor como um desejo, assim maiúsculo, de transcender a condição que o iguala aos demais seres humanos e de identificar-se com o ilimitado. Desse modo, a "enorme vontade de ficar" é como um porto, do qual o sujeito poético, movido por esse Amor, está sempre a partir: "O que é o meu Amor? Senão o meu desejo iluminado/ O meu infinito desejo de ser o que sou acima de mim mesmo/ O meu eterno partir da minha vontade enorme de ficar/ Peregrino, peregrino de um instante, peregrino de todos os instantes? [...]// O que é o meu ideal senão o Supremo Impossível? [...]".

O que é permanente em sua vida é a sensação de completo desamparo, mas esse é o preço que o eu lírico está disposto a pagar para manter iluminado o seu desejo de transcender a condição humana. Somente o "descampado", a extensão da paisagem, oferece-lhe o espaço necessário ao desdobramento de seus poderes, ou uma maneira de ser "perto de si do outro lado de si" - para empregar uma expressão de Collot -, ao possibilitar o arrebatamento de sua existência em direção ao futuro: "O que sou eu senão ele, o Deus em sofrimento/ O temor imperceptível na voz portentosa do vento/ $O$ bater invisível de um coração no descampado.../ O que sou eu senão $\mathrm{Eu}$ Mesmo em face de mim?". Além disso, o preço a pagar pela garantia ou promessa de segurança seria ainda mais alto do que os custos da peregrinação em que se lança. É o próprio Amor que adverte o sujeito poético: "é vã toda a palavra/ Que não repousa no seio trágico do abismo". Percebe-se, assim, que o abismo é o lugar por excelência não apenas desse Amor maior, desse ideal definido como o "Supremo Impossível", mas também de toda a palavra que não é vã - da poesia, talvez se possa dizer: "O que é o meu Amor, ai de mim! senão a luz passível/ Senão a estrela parada num oceano de melancolia/ O que me diz ele senão que 
é vã toda a palavra/ Que não repousa no seio trágico do abismo?". A atração do eu lírico pelo ilimitado, pelo "abismo", funde-se, portanto, com a sua procura da poesia - conforme sugere o texto acima comentado e como afirmam poemas que serão examinados posteriormente -, e essa fusão pode ser uma pista para identificar a relação que se estabelece entre a experiência poética e a experiência amorosa na obra de Vinicius de Moraes.

Percebe-se que a eleição do ilimitado como o Amor maior a ser buscado pelo sujeito poético parece configurar a forma como ele vive e concebe $o$ amor pela mulher. A existência desse elo entre os dois tipos de amor permite rever a interpretação que, em geral, é dada a alguns versos exaustivamente citados do "Soneto de fidelidade" (MORAES, 1974, p. 183), texto que integra Poemas, sonetos e baladas. Na última estrofe desse poema, o eu lírico inscreve a sua intenção no que se refere ao futuro que projeta para si: "[...] $\mathrm{E}$ assim, quando mais tarde me procure/ Quem sabe a morte, angústia de quem vive/ Quem sabe a solidão, fim de quem ama// Eu possa me dizer do amor (que tive):/ Que não seja imortal, posto que é chama/ Mas que seja infinito enquanto dure". Esses versos têm sido lidos como uma vontade expressa pelo sujeito poético de que o amor seja intenso enquanto existir. Porém, também é possível interpretá-los - não contrariando, mas complementando a outra leitura de que são objeto - como um desejo de que esse sentimento dure apenas enquanto conduzir o eu lírico ao infinito e, consequentemente, enquanto puder aproximá-lo dos mistérios da poesia.

Se o abismo e a poesia que em seu seio repousa não são ofertados, eternamente, nos olhos de uma única mulher, o eu lírico invocará a "mulher única", "espécie adorável de poesia eterna", como se lê em Novos poemas, no texto denominado "Invocação à mulher única" MORAES, 1974, (p. 140-142). Essa invocação o acompanhará em sua peregrinação por "muitas léguas de mulher", para recorrer a uma expressão utilizada no poema "O amor dos homens", que faz parte de Para viver um grande amor. Prova disso é que, em Novos poemas, ele faz um "Poema para todas as mulheres" (MORAES, 1974, p. 157-158), e, ao falar de "Ariana, a mulher" (MORAES, 1974, p. 127-131), poema que compõe o livro homônimo, afirma "[...] E tudo em mim buscava Ariana e não havia Ariana em nenhuma parte". Ariana é o nome feminino daquilo que o próprio sujeito poético chama, em outro texto, de "Supremo Impossível". Como se vê logo depois, por ser inacessível, essa que é a "mulher única" leva o sujeito poético, já desesperado, a bradar: "Quem és que te devo procurar em toda a parte e estás em cada uma?/ Por que me persegues e me foges e por que me cegas se me dás uma luz e restas longe?". Entretanto, ele não obtém resposta: "Mas nada me respondeu e eu prossegui na minha peregrinação através da campina/ E dizia: Sei que tudo é infinito! - e o pio das aves me trazia o grito dos sertões desaparecidos [...]". 
Por sua vez, em "Elegia ao primeiro amigo" (MORAES, 1974, p. 174-176), que faz parte de Cinco elegias, o eu lírico repete que é "um homem de muitas mulheres", dizendo que as abandona se o "entediam" e que seguirá todas elas em seu caminho, aí descrito como "uma dispersão de pegadas/ Para o alto". Essa é a "missão" do sujeito poético, que deseja ser "amante" e que evidencia, nesse poema, a sua impossibilidade de manter-se ao lado de uma única mulher, pois ele só persevera na peregrinação, na busca. Ao mesmo tempo, esse homem reafirma a profunda ligação que possui com as mulheres ou com a "mulher única": "[...] e não me reste de tudo, ao fim/ Senão o sentimento desta missão e o consolo de saber/ Que fui amante, e que entre a mulher e eu alguma coisa existe". O elo que o liga às mulheres é maior do que tudo, inclusive do que o amor - e pressupõe um entendimento peculiar por parte do eu lírico do que seja fidelidade, uma vez que ele se declara fiel a todas elas e a nenhuma em particular -, como se verifica nos versos subsequentes: "Maior que o amor e a carne, um secreto acordo, uma promessa/ De socorro, de compreensão e de fidelidade para a vida".

Considerando-se a análise desenvolvida até aqui, o "Soneto do maior amor" (MORAES, 1974, p. 202), que integra Poemas, sonetos e baladas, poderia ser lido como uma síntese do modo pelo qual o sujeito poético encena a relação que estabelece não apenas com a mulher amada, mas também com a paisagem na obra de
Vinicius de Moraes. Nas palavras do eu lírico, o desejo do infinito impossibilita sua dedicação a uma única mulher e, por isso, encontra correspondência no amor que ele manifesta à própria paixão amorosa e ao estado de poesia que esta lhe proporciona. A fidelidade à "lei" desse sentimento que muda a cada instante é o que levaria o sujeito poético a persistir na "eterna aventura": "Maior amor nem mais estranho existe/ Que o meu, que não sossega a coisa amada [...].// $\mathrm{E}$ que só fica em paz se lhe resiste / $\mathrm{O}$ amado coração, e que se agrada/ Mais da eterna aventura em que persiste/ Que de uma vida mal-aventurada". A preferência por viver "a esmo" o impediria, portanto, de permanecer no amor envelhecido: "Louco amor meu, que quando toca, fere/ $\mathrm{E}$ quando fere vibra, mas prefere/ Ferir a fenecer - e vive a esmo// Fiel à sua lei de cada instante/ Desassombrado, doido, delirante/ Numa paixão de tudo e de si mesmo". Essa "paixão de tudo e de si mesmo" - repetida com variações e enfatizada, também, pela intensidade e pela forma explícita com que é declarada - é a principal característica do amor que invade o eu lírico e, ao que tudo indica, a base a partir da qual é erigida sua identidade como poeta. Entretanto, a leitura de alguns versos de Vinicius de Moraes mostram que esse pode não ser o único elemento a explicar a relação que a experiência amorosa mantém com a poesia na obra do escritor.

O poema intitulado "O amor dos homens” MORAES, 1974, (p. 301-304), 
em Para viver um grande amor, aponta nessa outra direção. Na primeira estrofe desse longo poema, o eu lírico projeta o momento de repouso que se seguiria à consumação do amor. Nesse instante, ele seria assaltado pela crença momentânea de que havia, enfim, encontrado "a flor extrema", ou seja, a mulher que o faria dar por terminada a "busca": "[...] Tu me perguntarás/ $\mathrm{E}$ eu te responderei, a olhar com ternura as minhas pernas/ Que o amor pacificou, lembrando-me que elas andaram muitas léguas de mulher/ Até te descobrir. Pensarei que tu és a flor extrema/ Dessa desesperada minha busca [...]". Porém, o sujeito poético logo revela que a "unidade" plena com essa mulher não teria como ser alcançada.

A tristeza que ele, "de repente", viria a sentir é uma consequência da constatação a que chega quando segue projetando as suas atitudes e as da amada. O obstáculo mais evidente a interpor-se entre os amantes são os comportamentos distintos que apresentam e que, segundo o eu lírico, deriva de uma diferença existente entre a "natureza masculina" e a "natureza feminina". Ele é "solitário como um homem" e, apesar de apaixonado, mantém-se "vagamente atento/ Aos ruídos longínquos da cidade", enquanto ela se mostra, do ponto de vista daquele que a observa, absurdamente atarefada num "cotidiano" que é só dela. O distanciamento da amada - "[...] perdida, ah tão perdida/ De mim" -, que se acha concentrada em seu universo íntimo e/ ou nos objetos e ações que compõem o ambiente doméstico, desperta o ciúme no sujeito poético. Ele se considera excluído do mundo habitado por essa mulher. Até essa passagem, ainda é possível pensar que aquilo que os separa é, acima de tudo, a falta de aptidão da amada para seguir com ele em sua busca do infinito: "Sentirei alguma coisa que se fecha no meu peito/ Como pesada porta. Terei ciúme/ Da luz que te configura e de ti mesma/ Que te deixas viver, quando deveras/ Seguir comigo como a jovem árvore na corrente de um rio/ Em demanda do abismo".

Todavia, a leitura dos versos subsequentes leva a supor que esse não é o principal fator a atormentar o eu lírico e a afastar os dois amantes. A "angústia" de que ele é tomado vem do "limite" que os "antagoniza". E esse limite não é, ou não é apenas, a "natureza feminina" do ser amado ou "a redoma de ar" que "circunda" essa mulher - [...] o espaço/ Que separa os nossos tempos"-, encerrando-a num lugar fechado, enquanto ele anseia pelo infinito. Embora, o sujeito poético alegue que ela lhe rouba o sossego por ser mulher - por obedecer "a um ritmo diverso" e possuir "seios, lágrimas e pétalas" -, o que o perturba é a inacessibilidade à interioridade da amada, que, pelo simples fato de ser outra pessoa, jamais estará completamente sob o seu domínio: “[...] Tua forma/ É outra: bela demais, talvez, para poder/ Ser totalmente minha. [...]”. A posse física da mulher dá a ele a impressão de que ela pode ser subjugada: "Fora de mim/ És pura imagem; 
em mim/ És como um pássaro que eu subjugo, como um pão/ Que eu mastigo, [...]/ como um resto de nuvem/ Sobre que me repouso". Entretanto, contrariando o desejo do sujeito poético e alimentando o seu ciúme, a amada insiste em não lhe pertencer: "[...] Mas nada/ Consegue arrancar-te à tua obstinação/ Em ser, fora de mim - e eu sofro, amada/ De não me seres mais. [...]".

A sensação de impotência do eu lírico diante do véu que lhe impede de conhecer a consciência do "outro" é agravada quando ele identifica nesse ser do sexo feminino poderes que estão fora do seu alcance: o "ventre fértil" e os seios, que são "cântaros de leite" capazes de saciar a "fome universal". Assim, aquele que, em outros poemas, julgava-se superior ao provocar, com a sua partida, o sofrimento da amada, sente-se, no texto intitulado "O amor dos homens", inferior a essa mulher que, estando a sua frente, mantém-se distante, imersa numa existência que ele desconhece e da qual não participa, mas que solicita sua atenção: "[...] És mulher/ Como folha, como flor e como fruto/ E eu sou apenas só. Escravizado em ti/ Despeço-me de mim, sigo caminhando à tua grande/ Pequenina sombra. [...]". Tentado a acompanhar e a decifrar os gestos e os pensamentos secretos da amada, o sujeito poético despede-se de si próprio e, mesmo reconhecendo que o seu esforço é vão, vê-se escravo da curiosidade e do desejo que o dominam, tornando o seu olhar cativo: "Vou ver-te tomar banho [...]/ Enquanto busco em minha mente algo que te dizer/ De estupefaciente. Mas tudo é nada".

Nesse poema, então, aquilo que amedronta o eu lírico, e que pode arrastá-lo à perda de si mesmo, não é o tédio que teria origem no desejo saciado e no amor envelhecido, mas exatamente o seu oposto: o segredo, a estranheza, o incognoscível, a surpresa iminente, que sempre estarão escondidos nos olhos da amada, a despeito da aparente sensação de familiaridade ou previsibilidade que pode surgir numa longa convivência. São esses os perigos que levam o sujeito poético ao desespero e o fazem imaginar as mais difíceis, extremas e absurdas formas de fuga e de ascensão: “[...] $\mathrm{E}$ então desesperado/ Parto de ti, sou caçador de tigres em Bengala/ Alpinista no Tibet, monge em Cintra [...]/ Dedicam-me enormes reportagens. Fazem-me/ O 'Homem do Ano' e candidato certo ao Prêmio Nobel". Como se percebe a seguir, nenhum risco é maior para ele do que aquele a que se acha exposto frente à impassibilidade e à "radioatividade" da amada, ela, sim, indomável e capaz de instaurar o caos no mundo a sua volta, até mesmo, ou sobretudo, quando pratica uma ação supostamente banal e inocente, como a de comer um pêssego, por exemplo: “[...] Teu lábio/ Inferior dobra-se sob a polpa, o suco/ Escorre pelo teu queixo, cai uma gota no teu seio/ $\mathrm{E}$ tu te ris. Teu riso/ Desagrega os átomos. [...] / Só os gens de meus tataranetos poderão dar prova cabal de tua imensa/ Radioatividade. [...]”. É, portanto, para 
escapar da incerteza, da insegurança e do infinito que se ocultam no cotidiano, que o eu lírico aventura-se em direção ao "Supremo Impossível". Sua busca também é uma fuga.

O sujeito poético ama essa mulher de forma extrema - “[...] $\mathrm{E}$ eu te amo/ De morrer [...]" - e, por isso odeia tudo o que, nela, não lhe pertence. $\mathrm{O}$ silêncio em que a amada se refugia e as memórias que povoam esse reduto conduzem-no à simulação de sua autodestruição, que seria antecedida de uma agressão àquela que 0 ameaça: "[...] Esbofeteio-a/ vou correndo cortar o pulso com gilete-azul”. Para se recuperar dessa espécie de morte simbólica - talvez uma tradução do sentimento de perda de si que o atormenta -, o eu lírico obedece à amada: "Fazes-me sugar tua carótida, numa longa, lenta/ Transfusão [...]". No entanto, assim que ela deixa de ser "sugada" por ele, o sujeito poético, sintomaticamente, sente-se traído: “[...] Eu convalescente/ Começas a sair: foste ao cabeleireiro. Perscruto em tua face. Sinto-me/ Traído [...]”. O sentimento de traição que experimenta ao defrontar-se, de novo, com o fato de que a amada não é totalmente sua intensifica no eu lírico a sensação de que ele está à mercê do poder destrutivo dessa mulher "[...] Mas te aproximas/ Só com o casaco do pijama e pousas/ Minha mão na tua perna. $\mathrm{E}$ então eu canto:/ Tu és a mulher amada: destrói-me! Tua beleza/ Corrói minha carne como um ácido! Teu signo/ É o da destruição! Nada resta/ Depois de ti senão ruínas! [...]”. A amada possui uma existência que não depende do sujeito poético, nem lhe é acessível. Essa constatação desperta nele outro sentimento, que é o de inutilidade, e leva-o a ver sua permanência ao lado dela como algo "intolerável”: "[...] Tu és o sentimento/ De todo o meu inútil, a causa/ De minha intolerável permanência [...]".

É verdade que essa mulher impassível, capaz de expor a fragilidade do homem por meio do fascínio que exerce sobre ele e o subjuga, é abençoada por propiciar-lhe a descoberta de um mundo estranho no centro da atmosfera familiar: "[...] Abençoada sejas: tu e a tua/ Impassibilidade. Abençoada sejas/ Tu que crias a vertigem na calma, a calma/ No seio da paixão. Benditas seja/ Tu que deixas o homem nu diante de si mesmo, que arrasas/ Os alicerces do cotidiano [...]". O caos instaura-se na presença da amada, inclusive, porque ela tem o poder de alterar as noções de tempo, algo que parece ser desejado pelo homem, como indicam os versos "[...] Possa ela, cada dia/ Renovar o tempo, transformar/ Uma hora num minuto [...]", que remetem à seguinte passagem de um conhecido soneto de Camões (1992, p. 60) acerca dos efeitos provocados no eu lírico pela visão de sua "senhora": "Numa hora acho mil anos; e é de jeito/ Que em mim anos não posso achar uma hora".

Entretanto, no que se refere à obra de Vinicius de Moraes, também é verdade que essa mulher, embora detenha em si a magia e o abismo que conduzem à poesia - “[...] Mágica é a tua face/ Den- 
tro da grande treva da existência. Sim, mágica/ É a face da que não quer senão o abismo/ Do ser humano [...]" -, somente pode acompanhar o homem como uma imagem que ele guarda na memória. Distante fisicamente, mas presente na saudade que o sujeito poético carrega consigo, ela já não o ameaça e, talvez por esse motivo, seja mais amada do que nunca: “[...] Caminhe ela/ Lado a lado do homem em sua antiga, solitária marcha/ Para o desconhecido [...]/ ela que agora/ Longe de mim, perto de mim, vivendo/ Da constante presença da minha saudade/É mais do que nunca a minha amada e a minha amiga[...]". Desse modo, a amada torna-se não apenas insuperável como também uma "inseparável inimiga".

Na poesia de Vinicius de Moraes, tal como afirma Collot a respeito da experiência amorosa, o encontro desse Outro que é a amada revela ao homem, "para além do cosmos ordenado e acabado, um mundo inteiro em estado nascente". Porém, o caos rico de possibilidades que a mulher faz avultar provoca a sensação de que a terra se perde antes de se mostrar nova e, imerso nesse turbilhão, o eu lírico sente-se dispensável, impotente, diminuído e em perigo. Talvez por essa razão, apesar de abençoá-la - e de desejar o universo de mistério que ela desencadeia e que abre caminho para a poesia -, o sujeito poético empregue, para definir a amada, uma metáfora paradoxal e ambígua, em que o sentido positivo transforma-se em negativo. Tal metáfora refere-se a essa abertura do espaço ao ilimitado, por ela promovida e supostamente visada por ele, mas, ainda assim, configura-se como um elemento que intimida o eu lírico e que não é genuíno; falta-lhe autenticidade. A mulher é "Uma contrafação da aurora", e o significado de engano ou fingimento que a palavra "contrafação" contém relaciona-se, talvez, ao temor que esse homem possui: o de que a permanência nesse novo universo surgido por obra da amada traga para ele a ruína e a corrosão. Assim, se aquilo que a mulher lhe oferece - um horizonte que, de acordo com Collot, não é o "Desconhecido radical", e sim uma reserva inesgotável aberta ao conhecimento - representa para o eu lírico uma ameaça maior do que o "Desconhecido radical”, então, é na direção deste último que ele se lança, ou, segundo suas próprias palavras, na direção do "Supremo Impossível". O "Poema dos olhos da amada" (MORAES, 1974, p. 334-335), incluído em Antologia poéti$c a$, reforça essa ideia e propicia uma compreensão mais aprofundada a respeito da eterna peregrinação do eu lírico, que ele atribui a uma promessa de fidelidade a todas as mulheres e à atração que sente pelo "Supremo Impossível".

Se em "Solilóquio", texto já comentado, o sujeito poético afirma diferenciar-se dos outros, os "puros", os "crentes", por ser descrente e por desejar perder-se no mar, no "Poema dos olhos da amada", as posições parecem inverter-se, pois aí a mulher é o Outro, e é ela que apresenta as qualidades que, no poema antes exa- 
minado, distinguem o eu lírico e/ou são buscadas por ele. Na segunda estrofe de "Poema dos olhos da amada", percebe-se que, nos olhos da mulher, estão contidos todo o mistério, toda a aventura e, também, os naufrágios: "Ó minha amada/ Que olhos os teus/ Quanto mistério/ Nos olhos teus/ Quantos saveiros/ Quantos navios/ Quantos naufrágios/ Nos olhos teus". Além disso, na terceira estrofe, o sujeito poético, ao mesmo tempo em que se declara descrente, precisa imaginar a existência de Deus para explicar a origem dos olhos da amada, que possuem atributos incomparáveis: "Ó minha amada/ Que olhos os teus/ Se Deus houvera/ Fizera-os Deus/ pois não os fizera/ Quem não soubera/ Que há muitas eras/ Nos olhos teus". Por fim, a abertura da quarta e última estrofe revela que é a amada, e não ele, que traz nos olhos a descrença: "Ah, minha amada/ De olhos ateus [...]". Nos versos que seguem, verifica-se, ainda, que, se em outros poemas, a mulher era abandonada pelo homem - que partia logo após o enlace -, em "Poema dos olhos da amada", o eu lírico desejaria crer, mas não crê, na possibilidade de vê-la diante de si com um olhar de súplica: "[...] Cria a esperança/ Nos olhos meus/ De verem um dia/ O olhar mendigo/ Da poesia/ Nos olhos teus". (p. 334-335) Maria Rita Kehl interpreta o "olhar mendigo da poesia" como o olhar do próprio poeta, que implora "a algum Deus a graça de ver este olhar pedinte nos olhos da amada, pois quem pede se revela: revela a carência". Conforme explica a ensaísta, se "o olhar da amada mendigasse, deixaria de ser inacessível, indecifrável [...]" (KEHL, 1995, p. 412), porém isso não acontece.

\section{$\mathrm{O}$ infinito como um fim}

A análise desenvolvida demonstra que, em algumas passagens da obra de Vinicius de Moraes, tal como ocorre em "Minha mãe", primeiro poema mencionado neste trabalho, o eu lírico encontra-se dividido entre o espaço que o "prende" e o infinito que o "chama" - ambos o atemorizam e o fascinam -, dizendo-se apavorado com a ideia de ter de escolher um dos dois e de renunciar ao outro. Entretanto, em vários outros poemas, o sujeito acaba fazendo uma opção. Como é assaltado pelo medo de permanecer ao lado de uma única mulher e ser consumido por ela, ao abismar-se nos olhos da amada que nunca serão completamente seus, ele prefere fugir antes de ver-se destruído e, assim, aposta na busca de todas as mulheres ou da "mulher única", que se realiza através da fuga rumo ao "Supremo Impossível". À dispersão amorosa corresponde a dispersão no espaço. 


\section{Identité et altérité: Le jeu de l'amour e de la poésie dans Vinicius de Moraes}

\section{Résumé}

Cet article fait une analyse de l'oeuvre poétique de Vinicius de Moraes, dans le but de montrer que, dans l'oeuvre de cet auteur, la question de l'identité e de l'altérité est imbriquée avec le thématique de l'amour. La perte de soi, déclenchée dans le sujet par l'amour, donne accès a une expérience encore plus radical de l'altérité: c'est la route trouvée par le je dans la langage, dans la poésie. Le fait que l'amour, en sa présence ou son absence, est la route trouvée par le je lyrique dans l'espoir de se constituer comme poète est mis en évidence par le façon dont les poèmes analysés mettent en scène la relation que le sujet établie non seulement avec la femme aimée mais également avec le paysage. Pour analyser la poésie de Vinicius de Moraes dans l'optique de l'identité e de l'altérité, nous adoptons la perspective de la critique thématique d'origine française, en prenant comme support les thèses de Michel Collot sur la constitution de la subjectivité e sur les relations de sujet avec le espace, ainsi que sur les aspects dont l'expérience poétique et l'expérienceamoureuse ont en commun.

Mots clés: Identité. Altérité. Paysage. Expérience poétique. Expérience amoureuse.

\section{Notas}

1 Cf. original: "[...] on peut dire [...] que le paysage, selon la critique thématique, unit étroitement une image du monde, une image du moi, et une construction de mots". (salvo indicação, todas as traduções do original são nossas)

2 Dans le jeu grave de l'amour et de la poésie, tout se trouve remis en jeu: le je, le monde et les mots y perdent leurs contours et leur identité, pour 'prendre corps d'horizon', c'est-à dire s'ouvrir à une dimension d'altérité qui les transfigure et les ilimite [...]."

3 "Pour voir autrement les choses, "l'imagination poétique... dépose sa souveraineté, l'autorité de son point de vue, et adopte celui de l'autre [...]."

4 "Elle ouvre alors un horizon, qui n'est plus l'Inconu radical, mais une réserve inépuisable ouverte à la co-naissance [...]."

5 "Sa reencontre révèle, au-delà du cosmos ordoné et achevé, tout un monde à l'état naissant [...]."

6 "Et dans la relation amoureuse, la 'terre' 'se perd' avant de se découvrir 'nouvelle'."

7 "[...] le regard de l'Autre [...] est en effet le foyer visible de ce point de vue sur le monde qui me restera toujours invisible."

8 "Et si l'amour aboutissait à une totale fusion des consciences, il ne donnerait plus lieu à la parole ni à la poésie. C'est dans la mesure même où autrui m'est invisible qu'il me parle, et que j'éprouve le besoin de lui parler et de parler de lui."

9 “Qu'est-ce que l'amour ou la poésie, si ce n'est le déchiffrement toujours recommencé de ces signes énigmatiques venus de l'Autre ou de l'horizon?"

\section{Referências}

CAMÕES, Luís Vaz de. Lírica. Rio de Janeiro: Nova Fronteira, 1992.

COLLOT, Michel. La poésie moderne et la structure d'horizont. Paris: PUF, 1989.

. Les enjeux du paysage. Bruxelles: Ousia, 1997.

Do horizonte da paisagem ao horizonte dos poetas. Tradução de Eva Nunes Chatel. In: ALVES, Ida; FEITOSA, Marcia Manir 
Miguel (Orgs.). Literatura e paisagem: perspectivas e diálogos. Niterói: Ed. da UFF, 2010. p. 205-217.

Pontos de vista sobre a percepção de paisagens. In: NEGREIROS, Carmem; ALVES, Ida; LEMOS, Masé (Orgs.). Literatura e paisagem em diálogo. [S.1.]: Edições Macunaíma, 2012. p. 11-28. Disponível em: <http:// edicoesmakunaima.com/catalogo/2-critica-literaria/12-literatura-e-paisagem-em-dialogo>. Acesso em: 4 set. 2012.

KEHL, Maria Rita. Masculino/feminino: o olhar da sedução. In: NOVAES, Adauto (Org.). O olhar. São Paulo: Companhia das Letras, 1995. p. 411-423.

MORAES, Vinicius de. Poesia completa e prosa. Rio de Janeiro: José Aguilar, 1974.

PESSOA, Fernando. Obra poética. Rio de Janeiro: Nova Aguilar, 1995. 